\title{
Populism: Utility of its Approaches and the Prospects of the Phenomenon's Resurgence in America
}

\author{
Daniel Abankwa \\ University of Delaware, United States \\ abankwadaniel@yahoo.com
}

\begin{abstract}
Populism in the twenty-first century became prominent in scholarly circles following Brexit and the 2016 electoral victory of Donald Trump. As democracy and globalization enthusiasts least anticipated these two monumental events in modern history, much emphasis came to be placed on the nature of populism and what conditions led to its manifestation in contemporary times. Working within this background, this study aims to review the ideational, political strategy and discursive approaches to the populism phenomenon and unpack the relative utility of each approach. I offer a thoughtful perspective that while the ideational approach's "thin-centered" strand has the tendency to blur the boundaries of populism and lead scholars to accept "anything" as populism; it nevertheless enables us to comprehensively capture populism usage in multiple contexts. Further, I advance the notion that the 2020 electoral defeat of Donald Trump should not be misconstrued as the end or weakening of right-wing populism; the present state of American politics makes it ripe for populism resurgence.
\end{abstract}

Keywords: Populism, ideational approach, democracy, elections, policy.

\section{Introduction}

The political successes of Donald Trump, Viktor Orbán, and Boris Johnson rekindled much scholarly and journalistic attention to populism. Scholars then proceeded to propose the conceptual elements upon which we can use to identify ideologies, practices and political systems as populist. Brubaker (2017) for example prioritized the "claim to act in the name of the people" as an essential element of populism. The people in this sense may be politically and economically distinct from elites and culturally different from immigrant and refugee populations (Brubaker, 2017, p. 364). Müller (2017) in his account of populism asserts that it is not a sufficient condition to label as populist any political actor who is critical of elites. Because many politicians have historically run against Washington and elites, they could have easily been called populist but for him, claims and rhetoric bordering on antipluralism are essential for one to be considered a populist and not only the anti-elitist rhetoric. Goodhart (2017) pins populism in Britain on issues dividing the "anywheres" and "somewheres". As "anywheres" are embracive of European integration, immigration and more fluid gender roles, "somewheres" who are mostly socially conservative abhor them due to understandings that the three stand to threaten national identity, citizenship and traditional family values. These "somewheres" for Goodhart were most critical in the Brexit and Donald Trump's 2016 victory by virtue of their observation that established parties and party structures have consistently ignored their concerns and grievances. Not only were the "somewheres" peeved by immigration's tendency to challenge the demographic dominance of Whites, but they also harbor cultural and economic anxiety over the increasing pace of globalization.

According to Mouzelis (1985), political populism involves the process of drawing into the political space groups hitherto excluded or marginalized by employing anti-elite and pro-people ideology. This definition differentiates populism from simple revolutionary movements (China in 1949 and Cuba in 1953). Also critical to his argument is the need to exclude circumstances where political actors mobilize the common "people" to achieve temporary goals like the replacement of one leader by another and putting the people back to where they were after that goal has been accomplished. Political populism should in a sense bring about a significant broadening of political participation and a "permanent restructuring of the way in which the dominant and dominated groups are related to each other" (p. 344). Populism can also be seen as a "rhetorical style of communications" which border on two core dimensions (Norris \& Inglehart, 2019a). While the first dimension illuminates that the "people" are the only true and legitimate democratic authority and not elected representatives, the second is geared towards the claim that "established power-holders are deeply corrupt, and self-interested, betraying public trust" (Ibid, p. 66). This article reviews the different approaches to the study of populism, assesses the relative utility of each approach and finally unpacks why writing off populism in the wake of Joe Biden's election could be a significant error. 
It contributes to the populism literature by expanding the knowledge base on the ideational approach to the study of populism. I offer a thoughtful perspective in this article that while the ideational approach's "thincentered" strand has the tendency to blur the boundaries of populism and lead scholars to accept "anything" as populism; it nevertheless enables us to comprehensively capture populism usage in multiple contexts. The first section of the paper will focus on fleshing out the different approaches employed in the study of populism. In discussing the core assumptions of each of the approaches, I will also aim to situate in them how each approach compares with others in terms of relative strengths and shortfalls. The second section will unpack why I believe populism is an important topic within the field particularly in the contexts of democratic degeneration and political participation, and further zoom into discussions about the possibility of populism resurgence in post-Biden America.

\section{Approaches to the Study of Populism}

Ideational Approach to Populism: Scholars working with the ideational approach to populism take seriously the beliefs and ideologies of populists. They consider populism essentially as a set of ideas that exists in the mind of politicians and voters (Mudde, 2017; Hawkins, 2018; Hawkins \& Kaltwasser, 2018). The ideational approach to populism in its basic understanding advances the notion that the common discourse of populist parties and personalities reveals a way of looking at the political arena as a struggle between the will and aspirations of the common people (homogenous and moral community (Müller, 2017)) and an enemy elite (corrupt and self-serving). Essentially, this worldview tends to have an impact on a populist politician's mode of conduct in office and the resultant policies (Hawkins \& Kaltwasser, 2018). Populism as an ideology tends to also have an implication on research and the methodological approach needed to study it. Scholars who go by the ideology approach focus their attention on the "programmatic statements made by political actors, treating the latter as the primary units of analysis" (Gidron \& Bonikowski, 2013, p.7) which exist in the form of party literature like internal party memos, publications and official manifestos; to then aid in classifying political actors behind that literature as populists or otherwise.

Inquiry and research into these partisan texts are often conducted through qualitative content analysis focusing on small-sample cross-national comparisons (Mudde, 2007; Arter, 2010; Pankowski, 2010 as cited in Gidron \& Bonikowski, 2013). A broad definition of the ideational approach runs the risk of conflating critical differences within it. Among the ideational approach proponents who define populism as a set of ideas, there are scholars who conceptualize populism as a discourse and those who see it as an ideology. While the first is embedded in the form of claims or rhetoric premised on the dichotomy between the "elite" and the "people" (Bonikowski \& Gidron, 2016; Aslanidis, 2016), the second alternative as advanced by Mudde (2004) sees populism as a 'thin-centered ideology' that not only views society as divided into two; the 'pure people' and 'the corrupt elite' but essentially sees it as easily attached to other ideas. The thin-centered nature of populism sometimes comes down to the societal cleavages and grievances that are rendered politically salient by populists who essentially provide the framing of who belongs to the "people" and the "elite" (Mudde \& Kaltwasser, 2017, p. 21-22). Depending on the context of its emergence, populism as a set of ideas can adopt to diverse ideological shapes or appear in combination with other worldviews (Hawkins \& Kaltwasser, 2018; Taggart, 2000; Finchelstein, 2019).

This is primarily why given the context and the type of societal cleavage, we may at certain times have the right-wing variant of populism and other times, the left-wing variant (Rodrik, 2018). The "thin-centered" ideology as discussed by Mudde (2004, p. 19-20) elucidates the malleability of the concept of populism in terms of how it is easily attached or assimilated into other partial and full ideologies such as liberalism, socialism, nationalism and neoliberalism. Circumstances accounting for the manifestation of populism in Africa as evinced by scholars greatly lend credence to populism as a "thin-centered ideology". In the context of Zimbabwe, Ndlovu-Gatsheni (2009) has interrogated 'Mugabeism' as a populist phenomenon but one characterized by left-nationalism, anti-imperialism, nativism and patriarchy. Mugabe combined populist rhetoric and claims to advance both black nationalism and anti-imperialism which are ideologies on their own. The leaders who championed the emergence of the Economic Freedom Fighters (EFF) of South Africa have been labeled in the literature as populists (Posel, 2014) while being black nationalists and antiimperialists. 
The EFF does champion the pro-people agenda (Black South Africans) against culturally and economically distinct White elites who are conceived as having ripped native Black South Africans of their properties. The party came fully against the country's neoliberal economic policies that were rolled out after 1994 . To the EFF, these policies have facilitated the worsening conditions and inequalities among the poor in South African society (EFF, 2013). Like Bernie Sanders' populist challenge to the American capitalist class by reason that it is partly responsible for the suffering and inequalities in the United States, Malema, leader of the EFF has taken upon himself to champion a cause where the country's wealth is not concentrated in the hands of only a few in society. Looking at populism as a 'thin-centered ideology' enables us to account for the mix of ideologies that are embedded in Malema's claims and the EFF manifesto. He advances not only left-wing populism in the form of anti-capitalism and anti-neoliberalism but quite significantly, his claims and intended policies are laced with right-wing populism in the form of advancing the cultural 'struggle' between the "real black South African people" and White minority 'outsiders'. In her analysis of populism in Africa, Resnick (2017) points out that it can prove challenging to use a Western populism lens to examine African political systems. This is because, in the African context, there is the absence of "well-institutionalized political parties" which facilitates immense concentration of power in the executive.

In this regard, even when there is a strong personalistic rule and attack on liberal democratic institutions, it may be seen more as a norm rather than a deviation. The ascension to the presidency by Museveni of Uganda, Sankara of Burkina Faso (Skinner, 1988) and Sata of Zambia illustrates that although these leaders are tagged as populists in the literature (Rothchild and Gyimah Boadi, 1989: as cited in Resnick, 2017; Harsch, 2014; Larmer \& Fraser, 2007; Sishuwa, 2017; Cheeseman \& Larmer, 2015) by virtue of their self-characterization as pro-people and outsiders against the corrupt political establishment, their pursuance of unmediated connection between themselves and the people through undermining institutions was seen as a norm rather than a deviation from the general understandings in Western democracies. Applying a thin-centered approach to these populists as tagged by scholars, enables us to observe that populism as employed in different jurisdictions may react to existing institutions in a different way than observed in Western democracies. This is because the traditional assault of populists on institutions in the West seems to be nonexistent in the Ugandan and broader Sub-Saharan African context since there are usually never strong democratic institutions to attack anyway. In other respects, as the majority of politicians in Africa tend to capitalize and draw popular support by playing the ethnicity card, scholars have found that ethnic politics in the region often have a populist component to it herein known as 'ethnopopulism' (Sishuwa, 2017). Although historically understood as two mutually exclusive phenomena (ethnic politics and populism), Sishuwa (2017), Cheeseman \& Larmer (2015) show that political actors like Raila Odinga of Kenya and Michael Sata of Zambia appealed to voters by tactfully combining populism with ethnic politics. For the case of Zambia's Sata, it was shown that across the three historical epochs of his political life, he combined ethnic politics, populism and clientelism (Ibid).

To limit ourselves to a thick and boundary-specific conceptualization of populism may deny us the opportunity to account for populism as it played out in the South African, Zambian, Kenyan, and Zimbabwean contexts by clouding how populism can be combined with other ideologies as tools for seeking political change. Nonetheless, a downside to populism as a 'thin-centered' ideology is that it may open the floodgates to regard "anything" and all manner of ideologies to be regarded as populism as long as it has an "us against them' dimension to it. Consequently, and from a methodological perspective, using the ideational approach's 'thin-centered notion' may decrease the precision in case selection for qualitative or quantitative analysis. In terms of the utility of the ideational approach, Mudde (2004) believes that the ideational approach's proposition of the three key concepts (people, elite and general will) helps us in spotting what parties and actors can be considered as populists. For example, going by the ideational approach enables us to easily contrast populism with elitism and pluralism. Going by this approach, therefore, if radical right parties do not share all the three constitutive elements of populism, then they fail to be called such. Further to Mudde (2017), the potency of the ideological approach in distinguishing populism from non-populism meets one of the core rules and conditions for conceptualization as evinced in Sartori (1970). As a critique of the discursive approach, Mudde (2007) asserts that populism can easily be termed 'demagogy' if only what it has to do is use the 'common' language and symbols that the 'people' can relate to and want to hear. 
Political Strategy Approach: The political strategy approach considers populism "as a means of building and/or maintaining political power based on the mass mobilization of supporters" (Barr, 2018, p. 44, 47). According to Gidron \& Bonikowski (2013), this approach entails variants that touch upon different aspects of political strategy as employed by parties and movements; namely policy choices and forms of mobilization and political organization (p. 10). The policy choices variant revolves around the policy positions that populists are oriented to take, be it on the economic or social dimension. For instance, policies bordering on proeconomic redistribution, nationalization of resources and policies oriented as anti-establishment tend to characterize left-wing populism as largely evident in most studies on populism manifestation in Latin America (Acemoglu et al., 2011; Madrid, 2008). In the context of the United States and Britain, such approaches may study right-wing populism embedded in anti-immigration policies and border controls in a way that populists use to signal to a fraction of the population (their base) that they are fulfilling the promises upon which they were voted for.

In terms of the political mobilization and organization variant of the political-strategy approach, Weyland (2001) asserts that populism serves "as a political strategy through which a personalistic leader seeks or exercises government power based on direct, unmediated, institutionalized support from large numbers of mostly unorganized followers" (Weyland, 2001, p. 14). This variant focuses not on what populists say, but what they do in terms of the methods and instruments they use in capturing and retaining political power. It further emphasizes "the type of political actor that seeks and exercises power; and the principal power capability which that political actor mobilizes as support basis" (Weyland, 2017, p. 55). Unlike other alternatives on winning political power solely by relying on established institutions such as informal groupings, institutionalized political parties or military establishments, this variant helps us to understand that populism may often revolve around a single individual political actor establishing personal preeminence and unconstrained leadership even when he emerges from the military. An example is Juan Peron of Argentina (Weyland, 1996). To further demonstrate their distance from the establishment, populists continue mobilizing their mass support and hold frequent elections and plebiscites (Ibid). By recognizing such widespread mass support, they then resort to unmediated mechanisms (TV and social media communications) for speaking to their base to maintain and strengthen their commitment and loyalty. Populism as a strategy kickstarts the process of drawing into the political space groups hitherto excluded or marginalized (Mouzelis, 1985).

The policy choices variant of the political strategy approach has the utility of shedding light on the features of populism in practice in terms of showing clearly how populists leaders make real-time policy choices rather than relying on mere ideas, words and speeches like the ideational and discursive approaches will have it (Weyland, 2017). According to Weyland (2017), ideational and discourse-centered approaches to populism may classify political actors like Marie Le Pen and Gianfranco Fini as populists, whereas these rightist extremist actors may not qualify as populists under a political strategy-based approach. A political-strategy approach will classify Le Pen and Fini not as populists but as radical right-wingers due to their unwillingness to soften their posture on their 'resentment-driven ideologies' which arguably tend to keep them confined to the fringes of political power. Unlike Trump, the two are unable to tailor their strategies and appeals in ways that would maximize their chances of capturing the government. Their strategy to stick to their dogmatic and extremist worldviews "predictably draw widespread rejection and hostility" (p. 105). Further, in the context of fascism and populism, a political-strategy approach serves as a relatively viable distinguishing tool between the two phenomena because not only does it stand a greater chance of illuminating how both share affinities in terms of mobilization strategies, but quite significantly it is able to unpack the observation that while fascists may employ violence against perceived 'enemies' as a way of appeasing and drawing mass support from their base, populists would rather employ non-violent means of achieving populist objectives and winning the trust and loyalty of their base.

Populism as a Discursive Style: The discursive approach comes down to the style of communication or language that a populist actor may choose to employ in constructing the people-elite dichotomy (Gidron \& Bonikowski, 2013). In this respect according to Kazin (1995), the communicative styles used by populist actors to spread populist ideas are just as important as the populist ideas themselves. He argues that it may be out of place to conceive of populism as an ideology that illuminates the core beliefs or motives of specific political actors, but rather it is ideal for populism to be seen as a mode of expression that can be "selectively" 
and "strategically" used by liberals or conservatives seeking to render salient a societal cleavage built upon the 'us' and 'them' notion. Approaching populism from a discursive angle comes with some methodological implications that researchers would have to follow to generate empirical knowledge. In terms of the unit of analysis, adherents of the discursive approach consider the specific instances of political expressions and trace how actors shape and re-shape their rhetorical style relative to their professed ideology. In terms of methodological approach, the most viable tools are interpretive research methodology with textual analysis (Gidron \& Bonikowski, 2013).

Laclau (2005) is seen in the populism literature as having advanced the notion that the difference between the 'us' against 'them' is an 'empty signifier' that can take many shapes based on the meaning (embedded in communication and political expressions) that populists actors ascribe to it by vocally identifying and drawing the boundaries for who are to be considered the 'us' against the other. One could argue that approaching populism from the discursive framework has more strength relative to the other two approaches because analyzing the discourse and identifying patterns and contradictions in the speeches of political actors may enable a political scientist to not only discern the idea or ideological inclinations of the populist actor but also to discern beforehand what kind of mobilization and organization strategies are likely to be employed. This point leads into Pauwels' (2011) observation that, to approach populism as an ideology does not necessarily take away the possibility that it has a particular discursive style to it as well; essentially, if populist actors aim to return power to the ordinary 'people', it thus should come as no surprise that they would use a form of communication and expression that the common people can easily relate to.

While scholars working within the ideational approach talk about the set of ideas harbored by populist actors, they however leave undertheorized how these ideas are communicated and expressed (Hawkins, 2018). Such under-theorization is a significant shortcoming of the ideational approach essentially because to sieve through the discursive styles, expressions and rhetoric of populists enable us to see how the framing of direct statements can have politically polarizing effects on constituents, especially when most populistoriented electorates may solely rely on speeches of populist candidates and incumbents to take political actions rather than resort to reading their intended policies in manifestos. For example, Duterte and Orban's populist ideas will have no effect on electorates if it is not spoken in a way that illuminates the people-elite antagonism. Aggrieved masses are most positioned to act on the spoken words of their populist leaders rather than resort to past records to sieve through their leaders' ideas or resort to policy documents. Words and framing are powerful and may have the strongest mobilizing force than just ideas.

Populism's Place in Comparative Politics: If anything, modernization theory (Lipset, 1959) and the causal pathways of economic development should lead us to democratization and not its reversal in Western countries. Until contemporary times, liberal democracy reigned supreme and radical parties seemed to have been sidelined for life, but now voters being fed up with liberal democracy have turned to authoritarian populism which has grown prominent from America to Europe and from Asia to Australia (Mounke, 2018). We are no longer in the moment where rule of law, checks and balances, powerful independent judiciaries are as viable as they used to be (Scheppele, 2016). In Orban's Hungary, judiciary, parliamentary controls and constitutional rule continue to be undermined (Lendvai, 2017). In a similar vein, the Philippines from the election of Duterte has experienced its share of democratic fatigue and degeneration. "The Philippines went from a bastion of human rights and liberal values in Southeast Asia to a new haven for "Asian values" and strongman leadership" (Heydarian, 2017, p. 7). Similar observations had been prevalent in the rules of Juan Peron of Argentina in 1946, Andreas Papandreou of Greece in 1981, Alberto Fujimori of Peru in 1990, Silvio Berlusconi of Italy in 1994, Hugo Chavez of Venezuela in 1998 and Rafael Correa of Ecuador in 2007 (Pappas, 2019). These populists once in power propelled a system that was democratic but not liberal (Mudde \& Kaltwasser, 2017) and advanced political polarization and deeper assault on institutions.

As strong institutions are an essential element to the sustenance of democracy, such assault on them should be of great concern to comparativists. The study of populism is essential in comparative politics because as Galston (2018) reveals, it shows that liberal democracy faces a number of internal challenges which had fallen at the blindside of scholars. Western liberal democrats had for a long period of time been focusing on how democracy dies in other places like when there were violent uprisings and coup d'états in the developing world but now find themselves turning to their own country (Levitsky \& Ziblatt, 2018). The study of populism 
reveals that there is another way to break a democracy. Although less dramatic, it is equally destructive (Ibid). Democracies now do not die at the hands of military generals, captains and colonels but of elected leaders-presidents who subvert the very process that brought them to power (Ibid). While there are no coup d'états, there are now the incessant declarations of martial law and suspension of decades-old constitutions and legal systems. In other respects, while populism tends to limit the viability of party competition by virtue of depicting competitors as evil or enemies of the people, one cannot dispute how the study of populism in advanced democracies has enhanced our knowledge on the modes of political mobilization and participation.

Populism as a political strategy does illuminate that when politicians come to the level of voters and become ordinary and unofficial, common people are driven to connect with them and further come out in large numbers to vote in elections. Arguably, a populist's down-to-earth appeal and their mobilization effects do not only drive populist supporters, but also mainstream party supporters who fear that their voting apathy and indifference may lead to the election of their worst possible candidate. On the wider democratization level, populism does illuminate the degree of pessimism that comparativists and even International Relations (IR) democratic peace theorists may harbor about the rate at which we might expect democracy to spread or be adopted. In much of Africa, Asia, Eastern Europe and Latin America, U.S. governments had historically used diplomatic pressure, foreign aid and other foreign policy tools to facilitate democratization and counter authoritarianism but according to Levitsky \& Ziblatt (2018), America is no more a democratic model and Trump posed a threat to global democracy given that he neither did enough to strengthen it in America nor propel its spread to countries prone to authoritarianism and strongman rule. The degree of pessimism about the spread of democracy may thus be warranted whenever populism comes into the picture.

\section{Prospects of Populism Resurgence in Post-Biden America}

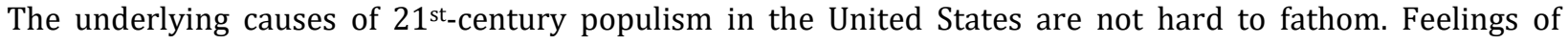
neglect among the American working class, pre-dominance of globalist policies, nostalgia for monocultural societies and rejection of postmaterial values have been studied to fuel populism. Not only were these issues central for populism surge in 2016, 2020 had its share of these sentiments but this time with the backing of a strong and unrelenting section of the public glued by conspiracy theories and misgivings about the electoral process. It is important to underscore that, absence of the 2020 pandemic handling fiasco and racial reckoning, America may have had another taste of populism as Trump's economic policies were popular among the corporate elite and upper-middle-class with beneficial outcomes trickling down to the poor in terms of access to jobs. The kind of mediums for propagating right-wing populist messages have even grown in number and their reach of audiences and now only need a purposeful and strategic leader willing to tap into it.

Trump's status as a political outsider resonated well with the majority of his base who largely bemoaned the disconnect between them and career politicians coupled with seeming threats about the predominance of lobbyists and special interests in Washington. Such personality of Trump brings up a challenging feat for potential right-wing populists who would not only have to demonstrate their outsider status to the populist base but be willing to accommodate and fan insider-outsider rhetoric and monocultural society sentiments. Some analysts do maintain the sustenance of the Grand Old Party (GOP) without Trump (Donatelli, 2021; Halon, 2021), but the least said about that the better. The more the party moves away from Trump, the less enthusiasm it is likely to bring to his populist base. This would not only create apathy among his base but more so dwindle the mobilization effect that Trump has on his voters. Political rhetoric bordering on "woke", "cancel culture" and fears of demise of Western civilization (Lahut, 2021; Hennessey, 2021; Moran, 2021) is likely to dominate 2022 and 2024 electioneering campaigns. Unless the GOP stick to discourse about policy and merits, the overemphasis on such rhetoric may largely deepen the divide within the GOP into those willing to stick with Trump versus those willing to ride with the Cheney's, the Romney's, the Murkowski's, and the Burr's.

The prospects of a splinter GOP are no joke. Local GOP censorships of congressmen and women following votes to convict Trump in his second impeachment speak to the assertion that Republican constituents are willing to hold Washington politicians to ransom should they demean Trump's influence in the party. Looking at the rise in desire among Republicans for a third party evidenced in Lincoln Project's rhetoric, one may 
prima facie argue that Trump's populist grip on the party will come at greater political costs to the Republican party fueled by those willing to move on from Trump. Sticking with Trump or Trump-endorsed candidates may likely translate into higher Republican voter turnout but may not automatically guarantee the White House. Indications about Mike Pompeo, Ron DeSantis, Ted Cruz, Tom Cotton or Tucker Carlson's potential nominations as leaders in the post-Trump GOP (Forgey, 2021; Bradner \& Warren, 2021; Colvin, 2021; Lahut, 2020; Dorman, 2021) are well in order as their unrelenting loyalty and support for Former President Trump persisted even after he left office. As the rhetoric of these personalities resonates well with Trump's base, a step towards the nomination of either one of them is likely to mobilize Republican voters. Gallup's 2021 survey results in Figure 1 demonstrate that a fairly large number of Republicans and Republican-leaning independents are willing to move more to the right. Although the survey findings are subject to significant change between 2021 and 2024, one might not rule out how the above-mentioned personalities are more drawn to champion an embrace of more conservatism and right-wing populism to fulfill the wishes and demands of Trump's base and Republicans in general.

Figure 1: Republicans Most Inclined to Want Party to Become More Conservative: Jan. 21 - Feb. 2, 2021

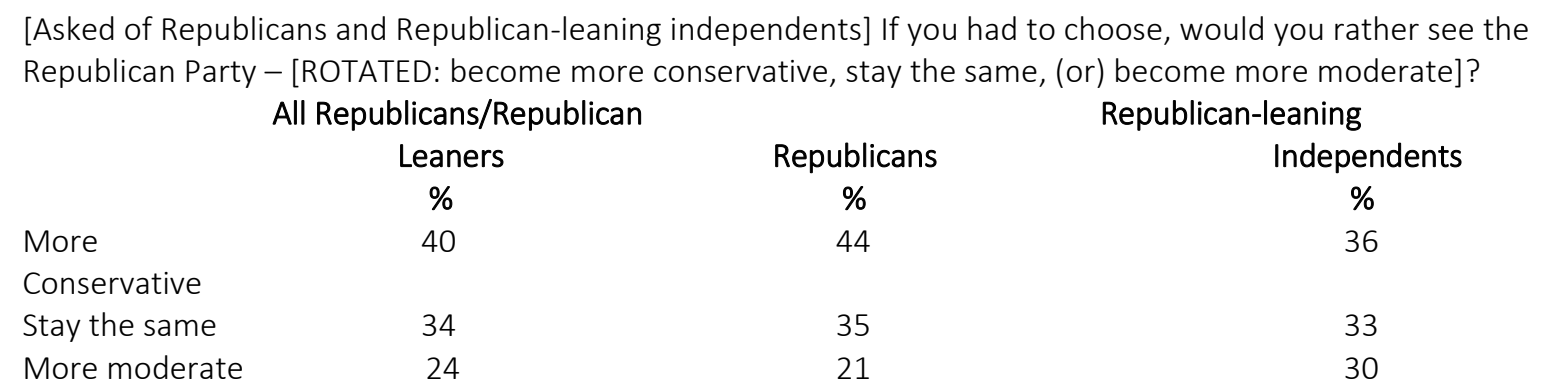

(Source: GALLUP, 2021)

Elizabeth Cheney's Ouster and the GOP's Future: Being vocal and unrelenting about Trump's way of politics certainly come with consequences and Elizabeth Cheney's censure and ultimate ouster as House GOP Conference chair was a prime example. The question is whether Cheney's position on Trump exonerates her should the GOP fail to take over the house in the 2022 midterm elections. With the president's party historically performing poorly in mid-term elections (McCarthy, 2018), a GOP landslide in 2022 midterms would only offer a rationalist explanation for the embrace of populism championed by Trump or Trumpendorsed candidates. One could easily predict that in the event of a landslide, GOP local leaders would be more emboldened to not only weed out moderate and anti-Trump Republicans but more so champion rhetoric that would seek to further delegitimize the 2020 election results and mobilize Trump's base for a massive turnout in 2024. Such actions are likely to be clothed under calls for a need for a formidable and united GOP intended to discredit allegations of internal civil war and a deviation from Lincoln's party. Stefanik's speech after being elected as GOP conference chair partly lends credence to this (Wagner et al., 2021). Republican leaders like Stefanik inclination to embrace Trump and his loyalists can be seen as part of a movement gradually veering away from discussions on the merits of what the GOP has to offer in terms of conservative policy initiatives to discussions resonating with Trump's base. According to Historian Nicole Hemmer, "Republicans are speaking to a very loyal, committed base that responds strongly to that kind of rhetorical red meat, that responds strongly to the fight, that wants to see their representatives take it to the left, whatever that looks like" (Bokat-Lindell, 2021, para. 11).

Agency of Independents and Moderate Republicans Pre and Post January 6, 2021, Capitol Riots: In Figure 2, Pre-January 6 Approval Ratings of President Trump among independents/Third Party voters sat at 46\% approval and 53\% disapproval (Alomran \& Winter, 2021). That for Self-Identified Republicans sat at $87 \%$ approval versus 13\% disapproval. Self-reported Trump 2020 voters approved the President's job by $92 \%$ percent with $8 \%$ disapproving of the job he was doing. After the events of January 6 as illustrated in 
Figure 3, his approval ratings fell to 36\% among independents/Third Party, 80\% among Self-Identified Republicans and $81 \%$ among Self-Reported Trump voters (Ibid). Factors that likely drove this drop in Trump's approval rating can be attributed not only to his handling of the events of January 6, but also his series of speeches aimed at inciting or mobilizing his supporters against the certification of election results and the consequential threat on the lives on legislators (Ibid). If these numbers are anything to go by, then one could argue that expelling Cheney from House Republican leadership may cost the Republican party as Cheney's current position on Trump likely resonate with moderate Republicans and independents and her ouster does little to mobilize them to vote for the Republican party in subsequent elections. The added advantage that Cheney's ouster gives to Democrats is the ability to fend off the cancel culture allegation levelled against Democrats with the assertion that the GOP itself cancels and rejects Republicans' views and perspectives that deviate from ones held by Trump loyalists. Looking at the figures, in order to win back the support of Independents and Republicans who thought Trump was culpable of inciting the riots, a broad and official condemnation from GOP leaders is non-negotiable. Although this step is very unlikely, diverse perspectives and opinions within the GOP should be largely embraced and entertained to court Independents and Moderate Republicans driven by conservative values and policies and not necessarily Trump loyalists.

Figure 2
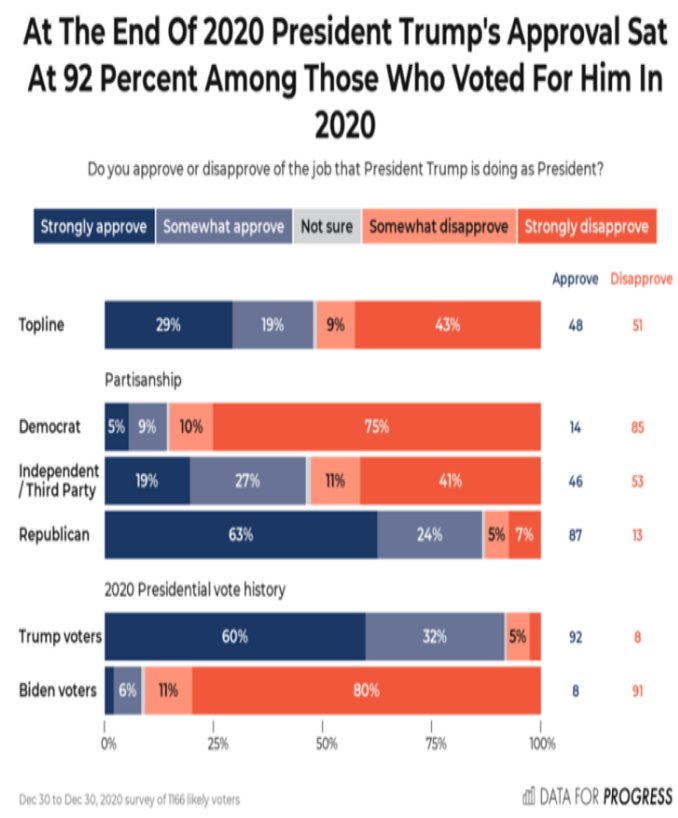

Figure 3

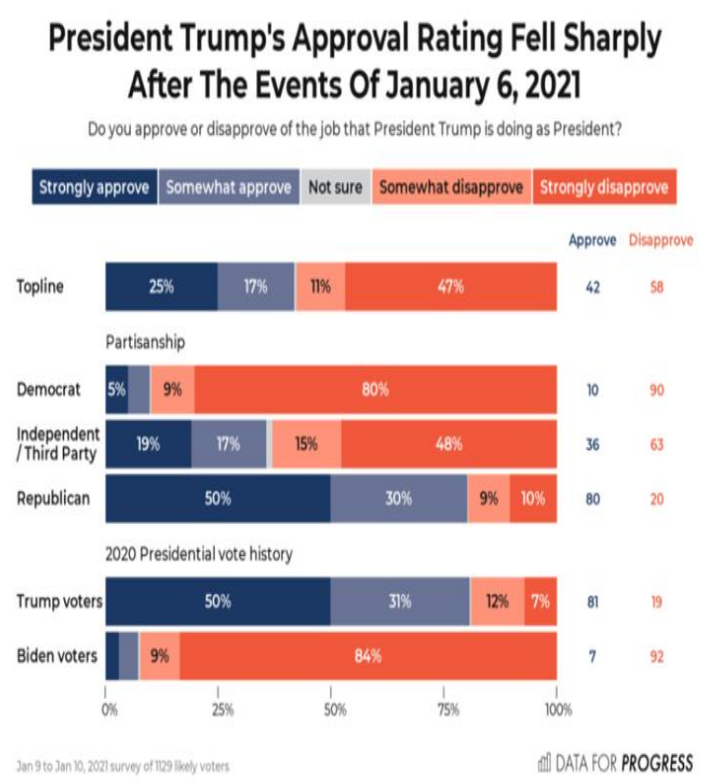

Source: Data for Progress (2021)

While Trump was unable to secure reelection, he had quite an impressive showing, and one may comfortably assume that his base is unrelenting to bring him back to the White House. Continuation of his rhetoric by popular GOP leaders, local GOP censures of anti-Trumpers and diminishing allegations of Trump's culpability in the Capitol riots sends a clear signal that right-wing populism is alive and well even after Trump's exit from power. It is prudent however for populism scholars to envision differing forms of populism should other Trump-endorsed candidates secure GOP nominations. For right-wing populism to be nipped in the bud in 2024 and beyond, swift attention towards the "left-behinds" in globalization is not optional. As the Rust Belt region was crucial to Joseph Biden's election, a well-planned industrial policy targeted towards that region will likely endear his administration to its constituents as some manufacturing giants are likely to be revived. This can be done by instituting far-reaching policies in Biden's American Jobs Plan to not only satisfy these sections of the public who not only lost their sources of livelihood due to the heavy manufacturing declined in 
the region but also harbor a great sense of nostalgia about the region as a once significant center of global manufacturing.

In fleshing out some of the causal pathways for the election of Trump and Erdogan, Esen \& Yardımcı-Geyikçi (2019) had argued that the failure of the political establishment to be responsive to voter preferences and act responsibly in policymaking once voted into office were prime mechanisms behind Trump and Erdogan's election. "Whereas responsiveness refers to the tendency of governments to respond to the demands and wishes of voters, responsibility requires acting prudently in policymaking and considering the wider electorate" (p. 446). It is high time mainstream parties conscientiously balance responsiveness and responsibility by devising policies and strategies that address the legitimate economic concerns of the 'leftbehinds in globalization and modernization. We surely would not expect a White-working class voter in Youngstown, Ohio (Gest, 2016) to vote for the Democratic party or pre-Trump Republican party if the latter's policies predominantly favor Wall Street and the capitalist class and do not contain a single policy component on the ways to revive some of the old local manufacturing industries which used to sustain their economic livelihoods.

\section{Conclusion and Recommendations}

The study sought to review the various approaches to the study of populism. The main assertion of the paper is that while the ideational approach's "thin-centered" strand has the tendency to blur the boundaries of populism and lead scholars to accept anything as populism, it nevertheless enables us to capture populism usage in multiple contexts. The paper also discussed the prospects of populism resurgence in post-Biden America by looking at Republicans' inclination towards more conservatism, prominent issues within the GOP after Trump's defeat and voters' reaction to the January 6, Capitol Riot. It is worth concluding that the global focus on economic growth and macro-economic stability one would argue have translated into growing inequalities with the political elites and college graduates mostly reaping its benefits. While the maintenance of macro-economic stability should be paramount, there should also be significant effort in ensuring that the wider electorates are not left off the radar in terms of benefitting from the economic gains. Mainstream parties and governments tend to listen and fulfill the demands of their base and do not often accommodate the demands of the wider electorate. These parties often make a portion of the electorates feel abandoned in times of crisis and populists as strategic as they are would capitalize on these grievances, mobilize them and finally capture power. The consequences then manifest in the form of attacks on liberal institutions and structures of government deemed partly responsible for the plight of their base supporters. The January 6, US Capitol riots demonstrated to the world that American democracy is fragile, and populism may be one of its most lethal threats.

Unless calculated attempts are made to unite the country and purge it from the high levels of political polarization among other factors, post-Biden America is likely to have another taste of populism. Populism brings up critical points that political scientists can no longer ignore. That is issues bordering on immigration and multiculturalism. These trends are increasingly seen as fanning the acceptance of right-wing populists and at the scholarly and policy level, the study of populism makes us aware of the fact that comparativists can no longer take for granted the fallouts of immigration and multiculturalism. It is highly critical that change, growth and transformation in the socio-economic make-up of Western countries benefit everyone because when that fails then populism would certainly find a voice and a leader who would not care about breaking century-old democratic rules to fulfill promises. Although the cultural dimension (Gest, 2016; Calhoun, 2017; Norris \& Inglehart, 2019) for the rise of populism especially right-wing and authoritarian populism is potent, one could assume that as the newer demographic cohorts (like Generation $\mathrm{Z}$ and millennials) were born and socialized into Western societies characterized by post-material values, increased immigration and multiculturalism, the aversion towards those trends may gradually fade away relative to that of the older population who spent majority of their formative years in material and monocultural societies. Those growing trends in the long run may not be viable sources of grievance for right-wing populists to capitalize on. The economic and anti-elite grievances however will still be viable targets if there is no equitable distribution of wealth and prosperity. 


\section{References}

Acemoglu, D., Egorov, G. \& Sonin, K. (2011). A Political Theory of Populism. NBER Working Papers 17306. National Bureau of Economic Research, Inc.

Alomran, I. \& Winter, E. (2021). Trump's approval rating dropping among Independents, Republicans. Data for Progress. https://www.dataforprogress.org/blog/2021/1/13/trumps-approval-rating-droppingamong-independents-republicans

Arter, D. (2010). The breakthrough of another West European populist radical right party? The case of the True Finns. Government and Opposition, 45(4), 484-504.

Aslanidis, P. (2016). Is populism an ideology? A refutation and a new perspective. Political Studies, 64(1_supple), 88-104.

Barr, R. R. (2018). Populism as a political strategy. In Routledge handbook of global populism (pp. 44-56). Routledge.

Bokat-Lindell, S. (2021). Why Can't the Republican Party Quit Donald Trump? New York Times. https://wwwnytimes-com.udel.idm.oclc.org/2021/05/18/opinion/cheney-trump-republicans.html

Bonikowski, B. \& Gidron, N. (2016). The populist style in American politics: Presidential campaign discourse, 1952-1996. Social Forces, 94(4), 1593-1621.

Bradner, E. \& Warren, M. (2021, March 26). Mike Pompeo visits Iowa as Republicans start to position themselves for 2024. CNN. https://www.cnn.com/2021/03/26/politics/mike-pompeo-iowatrip/index.html

Brubaker, R. (2017). Why populism. Theory and Society, 46(5), 357-385.

Calhoun, C. (2017). Populism, national and Brexit. Brexit: Sociological Responses, 57-76.

Cheeseman, N. \& Larmer, M. (2015). Ethnopopulism in Africa: Opposition mobilization in diverse and unequal societies. Democratization, 22(1), 22-50.

Colvin, J. (2021). Republican 2024 presidential hopefuls are making early moves as Trump mulls another run. Chicago Tribune. https://www.chicagotribune.com/nation-world/ct-aud-nw-republican-2024presidential-candidates-20210418-4thphwda55dkbivarabl7zp6fe-story.html

Donatelli, F. (2021, January 20). Trump Has Left the Building. Now the GOP Must Move On From HIm-Fast. Newsweek. https://www.newsweek.com/trump-has-left-building-now-gop-must-move-himfastopinion- 1562810

Dorman, J. (2021, April 17). A nicer version of Trump: Ron DeSantis is sized up by GOP donors ahead of potential 2024 presidential bid. Insider. https://www.businessinsider.com/desantis-trumprepublican-donors-2024-presidential-talk-2021-4

EFF. (2013). Economic Freedom Fighters Founding Manifesto: Radical Movement towards Economic Freedom in our Lifetime. https://effonline.org/wp-content/uploads/2019/07/FoundingManifesto.pdf

Esen, B. \& Yardımcı-Geyikçi, Ş. (2019). An Alternative Account of the Populist Backlash in the United States: A Perspective from Turkey. PS: Political Science \& Politics, 53(3), 445-450.

Finchelstein, F. (2019). From Fascism to populism in history. University of California Press.

Forgey, Q. (2021, March 4). Pompeo teases 2024 run: I'm always up for a good fight. Politico. https://www.politico.com/news/2021/03/04/pompeo-2024-run-473606

Galston, W. (2018). A populist challenge to liberal democracy. Journal of Democracy, 29(2), 5-19.

Gest, J. (2016). The new minority: White working-class politics in an age of immigration and inequality. Oxford University Press.

Gidron, N. \& Bonikowski, B. (2013). Varieties of populism: Literature review and research agenda. Weatherhead Center for Anternational Affairs. https://wcfia.harvard.edu/files/wcfia/files/gidron_bonikowski_populismlitreview_2013.pdf

Goodhart, D. (2017). The road to somewhere: The populist revolt and the future of politics. Oxford University Press.

Halon, Y. (2021, February 15). Hume: GOP needs to move away from Trump without alienating his supporters. Fox News. https://www.foxnews.com/media/brit-hume-gop-move-away-from-trumpwithout-alienating-his-supporters

Harsch, E. (2014). Thomas Sankara: An African Revolutionary. Ohio University Press.

Hawkins, K. A. (2018). The ideational approach. In Routledge Handbook of Global Populism (pp. 57-72). Routledge. 
Hawkins, K. A. \& Kaltwasser, C. R. (2018). Introduction: The ideational approach. In The Ideational Approach to Populism: Concept, theory, and analysis (pp. 1-24). Routledge.

Hennessey, M. (2021, March 13). Cancel culture is out of control-And Gen X is our only hope. Fox News. www.foxnews.com/opinion/cancel-culture-is-out-of-control-and-gen-X-is-our-only-hope.amp

Heydarian, R. J. (2017). The rise of Duterte: A populist revolt against elite democracy. Springer.

Jones, J. M. (2021, February 15). Support for Third U.S. Political Party at High Point. GALLUP. https://news.gallup.com/poll/329639/support-third-political-party-high-point.aspx

Kazin, M. (1995). The Populist Persuasion: An American History. Cornell University Press.

Laclau, E. (2005). On populist reason. Verso.

Lahut, J. (2020, October 21). Tom Cotton is already laying the groundwork in New Hampshire for a 2024 presidential run. Insider. https://www.businessinsider.com/tom-cotton-laying-groundwork-2024presidential-run-new-hampshire-2020-10

Lahut, J. (2021, April 6). Fox News is betting big on the "cancel culture" wars post-Trump. Insider. www.businessinsider.com/fox-news-cancel-culture-tucker-carlson-gutfeld-new-show-20214\%3Famp

Larmer, M. \& Fraser, A. (2007). Of cabbages and Kind Cobra: Populist politics and Zambia's 2006 election. African Affairs, 106(425), 611-637.

Lendvai, P. (2017). Orbán: Hungary's Strongman. Oxford University Press.

Levitsky, S. \& Ziblatt, D. (2018). How democracies die. Broadway Books.

Lipset, S. M. (1959). Some social requisites of democracy: Economic development and political legitimacy. American Political Science Review, 53(1), 69-105.

Madrid, R. L. (2008). The rise of ethnopopulism in Latin America. World Politics, 60(3), 475-508.

McCarthy, N. (2018). Historically, The President's Party Performs Poorly. In the Midterms (Infographic). Forbes. https://www.forbes.com/sites/niallmccarthy/2018/10/09/historically-the-presidentsparty-performs-poorly-in-the-midterms-infographic/?sh=2e9c6b526732

Moran, L. (2021, April 2). Fox News Host Puts The Blame For "Woke" Military on Michelle Obama. HuffPost. Huffpost.com/us/entry/us_6066dc18c5b68872efe564cc/amp

Mounke, Y. (2018). The people vs. Democracy: Why our freedom is in danger and how to save it. Harvard University Press.

Mouzelis, N. (1985). On the concept of populism: Populist and clientelist modes of incorporation in semiperipheral polities. Politics \& Society, 14(3), 329-348.

Mudde, C. (2004). The populist zeitgeist. Government and Opposition, 39(4), 541-563.

Mudde, C. (2007). Populist radical right parties in Europe (Vol. 22). Cambridge University Press.

Mudde, C. (2017). An ideational approach. In The Oxford handbook of populism (p. 27). Oxford University Press.

Mudde, C. \& Kaltwasser, C. R. (2017). Populism: A very short introduction. Oxford University Press.

Müller, J. W. (2017). What is populism? Penguin.

Ndlovu-Gatsheni, S. J. (2009). Making sense of Mugabeism in local and global politics: So Blair, keep your England and let me keep my Zimbabwe. Third World Quarterly, 30(6), 1139-1158.

Norris, P. \& Inglehart, R. (2019a). Cultural backlash: Trump, Brexit and authoritarian populism. Cambridge University Press.

Norris, P. \& Inglehart, R. (2019b). Cultural backlash: Trump, Brexit, and authoritarian populism. Cambridge University Press.

Pankowski, R. (2010). The populist radical right in Poland: The patriots. Routledge.

Pappas, T. (2019). Populists in power. Journal of Democracy, 30(2), 70-84.

Pauwels, T. (2011). Measuring Populism: A Quantitative Text Analysis of Party Literature in Belgium. Journal of Elections, Public Opinion and Parties, 21(1), 97-119.

Posel, D. (2014). Julius Malema and the post-apartheid public sphere. Acta Academica, 46(1), 32-54.

Resnick, D. (2017). The Oxford Handbook of Populism. In Populism in Africa (p. 101). Oxford University Press.

Rodrik, D. (2018). Populism and the Economics of Globalization. Journal of International Business Policy, 1(12), 12-33.

Sartori, G. (1970). Concept misinformation in comparative politics. American Political Science Review, 103353(64), 4.

Scheppele, K. L. (2016). Worst Practices and the Transnational Legal Order (Or How to Build a Constitutional "Democratorship" in Plain Sight). Background Paper: Wright Lecture, University of Toronto. 
Sishuwa, S. (2017). I am Zambia's redeemer: Populism and the rise of Michael Sata 1955-2011 [Ph.D. dissertation]. University of Oxford.

Skinner, E. P. (1988). Sankara and the Burkinabe revolution: Charisma and power, local and external dimensions. Journal of Modern African Studies, 26(3), 437-455.

Taggart, P. (2000). Populism: Concepts in the social sciences. Open University Press.

Wagner, M., Macaya, M. \& Rocha, V. (2021). House GOP picks Stefanik to replace Cheney as conference chair. CNN. $\quad$ https://www.cnn.com/politics/live-news/liz-cheney-replacement-gop-vote-05-1421/h_a4f3bc7152ba5656dae273c6595a203f

Weyland, K. (1996). Neo-populism and neoliberalism in Latin America: Unexpected affinities. Studies in Comparative International Development, 31(3), 3-31.

Weyland, K. (2001). Clarifying a contested concept: Populism in the study of Latin American politics. Comparative Politics, 1-22.

Weyland, K. (2017). A Political-Strategic Approach. In The Oxford handbook of populism (p. 48). 